\title{
Patient Satisfaction with Antiretroviral Therapy Service and Associated Factors at Jimma Town Public Health Facilities, Southwest, Ethiopia
}

\author{
Matebu Gezahegn Snr' \\ Dawit Wolde Snr (D) \\ Yohannes Ejigu Snr' \\ Feyissa Tolessa Snr' \\ Diriba Fufa Snr $\mathbb{D}^{2}$ \\ 'Health Policy and Management \\ Department, Jimma University Institute \\ of Health, Jimma, Ethiopia; ${ }^{2}$ Pediatrics and \\ Child Health Department, Jimma \\ University Institute of Health, Jimma, \\ Ethiopia
}

\begin{abstract}
Background: HIV/AIDS is the greatest and most urgent public health problem that the world is facing today. Antiretroviral therapy (ART) is the treatment option for people infected by the HIV virus and helps them to lead longer and healthier lives and improve their quality of life. This study aimed to measure level of satisfaction and associated factors among patients receiving ART services in ART Clinics at Jimma Town Public Health Facilities, Southwest, Ethiopia.
\end{abstract}

Methods: Facility-based, cross-sectional study was employed from March to April, 2018 among 383 clients attending ART in three public health facilities of Jimma town. Data was collected using exit interviewer administrated pre-test structured, coded and entered using Epi-data version 3.5.1 and then exported and analyzed using SPSS version 20 software. Variables having $\mathrm{p}<0.25$ at bivariate analysis were fitted to multivariate analysis. OR, P-value and 95\% CI were computed to show the association of variables $(\mathrm{p}<0.05)$.

Results: A total of 383 clients involved in the study. The majority of the study participants, $253(66.1 \%)$, were females and $163(42.6 \%)$ were in $28-37$ age category. The overall satisfaction rate for ART service provision was $89.6 \%$. Patients were satisfied with the availability of ARV drugs, measures taken by health care providers to keep confidentiality and location of the clinic in the facility, $97.9 \%, 93.2 \%$ and $96.3 \%$, respectively. The findings of this study revealed statistically significant associations between the patients' satisfaction and duration of stay on ART and waiting time to get service $(\mathrm{p}<0.05)$. Those patients who stayed 36-60 months on ART treatment were $82.5 \%$ less likely to be satisfied than those who stayed less than 12 months on ART treatment (AOR=0.175, 95\% CI: 0.04-0.771).

Conclusion: Overall, most respondents were satisfied with ART services provision. Factors like duration of stay on ART and waiting time to get service should be taken into consideration to improve the patient's satisfaction.

Keywords: patient satisfaction, ART, public health facility, Jimma town

\section{Introduction}

Human Immunodeficiency Virus/Acquired Immunodeficiency Syndrome (HIV/ AIDS) is the greatest and most urgent public health problem that the world is facing today. Since the first cases of HIV-related immunodeficiency were identified, HIV has become a world-wide pandemic with millions of associated deaths. ${ }^{1}$ Globally, an estimated 33 million individuals are living with HIV/AIDS, a majority of whom are from sub-Saharan Africa, where an estimated 22.5 million people are infected. ${ }^{2}$ Ethiopia is one of the sub-Saharan African countries with the highest burdens of HIV/AIDS. ${ }^{1,3}$ The history of HIV epidemic
Correspondence: Matebu Gezahegn Snr Jimma University Institute of Health, Jimma, Ethiopia

Tel +2519-42-63-29-24

Email matebug@gmail.com 
in Ethiopia was traced back to 1984. Since then, AIDS has claimed the lives of millions and has left behind hundreds of thousands of orphans. ${ }^{4,5}$ The government of Ethiopia responded to the HIV/AIDS epidemic as early as 1985. Consequently, a sector-wide reform has been implemented to improve the quality and accessibility of ART care service in health institutions throughout the country. ${ }^{3}$ The rapid expansion of the ART program provided an exceptional opportunity to rapidly scale up HIV/AIDS prevention, care and treatment services. ${ }^{6}$ As a result, free ART service were launched in public hospitals in 2005 as part of the service scaling-up. Since then, a total number of 738,976 patients are living with HIV and all of them require antiretroviral treatment (ART), however, only 426,000 are currently taking ARV even if there was a significant improvement related to the baseline of 13,000 ART patients in 2005/06. ${ }^{1,3}$ The numbers of ART providing facilities has also grown to 913 , of which about 765 are in health care centers. ${ }^{1}$ In Oromia, about 194,370 people were enrolled in the chronic HIV care, among which 15,586 were children $\leq 14$ years of age. A total of 115,334 ever started ART, of these 8953 were children $\leq 14$ years of age and 80,783 clients were still alive and active on treatment by June 2014 in the region. ${ }^{7}$ Patient satisfaction is the proxy indicator of health care quality as it gives information for health care managers and health care providers in meeting client values and expectations. Besides, a satisfied patient is more likely to develop a longer lasting relationship with their health care provider, leading to better compliance and continuity of care. ${ }^{8,9}$ Patient satisfaction is considered to be a health care outcome and predictor of treatment utilization and adherence to the care and support. The relationship between health care providers and patients (interpersonal skills) has also assumed to be the most influential factor for patient satisfaction. ${ }^{10}$ Patient satisfaction towards services has become a tool to gain attention and value amongst the patients as well as health care providers. ${ }^{11}$ Satisfied patients are more likely to comply with prescribed treatment and advice from doctors; they are also more likely to return for additional care especially for those on long term treatment like HIV/AIDS. ${ }^{12,13}$ Patients' satisfaction with health care services reflects the quality of services from the patients' perspective that supplements traditional indicators such as survival outcomes or processes of care. $^{9,12,13}$ The measurement of patient satisfaction might support health managers to evaluate the performance of health care delivery systems and identifying patients in need of additional attentions or other interventions to improve their health care. ${ }^{14,15}$ Determining patient satisfaction will enhance appropriate communication and building of stronger health worker patient relationship based on identified gaps and barriers to effective performance of HIV/AIDS prevention and control programs from the patients' perspective. ${ }^{9,15,16}$ The aim of the study was to measure level of satisfaction and associated factors among patients receiving ART services in ART Clinics at Jimma Town Public Health Facilities, Southwest, Ethiopia.

\section{Materials and Methods}

\section{Study Setting and Period}

The study was conducted in Jimma Town Public Health Facilities ART clinics at regular working hours from March to April, 2018. The town is found in Oromia regional state, Ethiopia in the southwest direction, which is $362 \mathrm{~km}$ away from the national capital Addis Ababa. The study focused on the three public health facilities which are providing antiretroviral treatment services for people living with HIV/AIDS (PLWHA). The facilities were Jimma University Medical Center (JUMC), Shene Gibe Primary Hospital and Jimma Health Center.

\section{Study Design, Participants, Sample Selection}

Facility-based cross-sectional study design was conducted. The study includes adults greater than or equal to 18 years who were interviewed in ART clinics of the three health Facilities. Sample size was calculated by using single population proportion formula with the following assumptions: proportion of patients satisfied with ART services to be $54.6 \%$, according to a study done in DilChora Hospital ${ }^{17}$ margin of error $\%$, confidence level of $95 \%$, considering $10 \%$ non-response rate. The calculated sample size was 383. The total sample size was proportionately allocated for each Health Facilities ART clinics depending on the average number of patients who visited the clinics one month prior to the start of the study. Then study participants were identified by systematic random sampling method. In addition, simple random sampling was done for the first patients to get the starting point. Thereafter, depending on sampling interval, patients coming to the clinics to be enrolled in the study until the required sample size was obtained. Data was collected using pre-tested structured questionnaires by exit interview in confidential rooms. The questionnaire was adapted from related literature with slight modifications made with the 
objective of this particular study and to fit with local context. The questionnaire in the beginning was prepared in English and then translated into Amharic and Afan Oromo and back to English to ensure consistency, and interview was administered by three professional nurses who can speak Afaan Oromo and Amharic fluently.

\section{Data Management and Analysis}

Data was checked and cleaned for completeness and accuracy, entered into EPI Info version 3.5.1 and then exported and analyzed using SPSS version 20. Bi-variate analysis was done and variables with $p$-value less than 0.25 were included in multiple logistic regressions analysis to control confounder and identify the most significant predictor of outcome variables. Respondents rated their satisfaction with various aspects of services provided, using a five-point Likert scale containing five items (1-strongly dissatisfied, 2-dissatisfied, 3-neutral, 4-satisfied, and 5-strongly satisfied). Responses for each five item question was summed and transformed to give an overall satisfaction score from 0 to 100 percent for each item used in the scales. ${ }^{18}$ Descriptive statistics was computed for the study variables and frequency distribution tables were used to describe most of the findings.

\section{Ethical Consideration}

Study was approved by Ethical Review Board (ERB) of Jimma University, Health Institute. Support letter and permission was obtained from Jimma University, Public Health Faculty. Permission letter to conduct the study was secured from Jimma Town Health Office and Jimma University Medical Center. Informed verbal consent was approved by Jimma University Health Institute Ethical Review Board and the study was conducted based on the Helsinki Declaration. Consent was obtained from each client after explaining the objectives of the study. Clients were assured that refusal to participate does not affect their care and services they are obtaining. Privacy and confidentiality was assured.

\section{Results}

\section{Socio-Demographic Characteristic of the Respondents}

A total of 383 respondents were the sample of the study. Based on the result of this study, the majority of respondents were females, 253 (66.2\%), age group 18-37, 163 (42.6\%). The finding also showed that most of the respondents had Elementary (1-8) school education, 149 (39.1\%), and employee of private sectors, 114 (29.8\%) (Table 1).

\section{Respondents Score on Satisfaction Measuring Items}

Among the total respondents ( $\mathrm{n}=383)$, most of the respondents were satisfied with the availability of ARV drugs, 375 (97.9\%); measures taken by health care providers to keep confidentiality, 357 (93.2\%); privacy during consultation, 356 (93.0\%); location of the clinic in the hospital (accessibility), 344 (89.8\%); and cleanliness and attractiveness of the clinic, 340 (88.8\%). On the other hand, most of the clients showed low satisfaction level with waiting time to get service, 301 (78.6\%); opening hours

Table I Socio-Demographic Characteristics of Respondents in ART Service in Jimma Town Public Health Facilities, 2018 $(\mathrm{N}=383)$

\begin{tabular}{|c|c|c|}
\hline Variables & Categories & Frequency (\%) \\
\hline \multirow[t]{2}{*}{ Sex } & Male & $130(33.9 \%)$ \\
\hline & Female & $253(66.1 \%)$ \\
\hline \multirow[t]{5}{*}{ Age Group } & $18-27$ & 46 (12\%) \\
\hline & $28-37$ & $163(42.6 \%)$ \\
\hline & $38-47$ & 99 (25.8\%) \\
\hline & $48-57$ & 44 (II.5\%) \\
\hline & 58 and above & 31 (8.1\%) \\
\hline \multirow[t]{5}{*}{ Marital status } & Single & $42(11 \%)$ \\
\hline & Married & $195(50.9 \%)$ \\
\hline & Divorce & $4 I(10.7 \%)$ \\
\hline & Widowed & $44(I I .5 \%)$ \\
\hline & Separated & $6 \mathrm{I}(15.9 \%)$ \\
\hline \multirow[t]{5}{*}{ Ethnic group } & Oromo & 172 (45.2\%) \\
\hline & Amhara & $87(22.7 \%)$ \\
\hline & Kafa & $49(12.8 \%)$ \\
\hline & Dawuro & $36(9.4 \%)$ \\
\hline & Others & $38(9.9 \%)$ \\
\hline \multirow[t]{5}{*}{ Education status } & Not able to read and write & 68 (I7.8\%) \\
\hline & Read and write only & $22(5.8 \%)$ \\
\hline & Elementary (I-8) & $149(39.1 \%)$ \\
\hline & Secondary (9-12) & 108 (28.2\%) \\
\hline & College and above & $36(9.4 \%)$ \\
\hline \multirow[t]{6}{*}{ Occupation Status } & Unemployed & 75 (19.7\%) \\
\hline & Government employee & $64(16.7 \%)$ \\
\hline & Farmer & $12(3.1 \%)$ \\
\hline & Merchant & 74 (19.3\%) \\
\hline & Private Employee & II 14 (29.8\%) \\
\hline & Others & 44 (1 I.5\%) \\
\hline \multirow[t]{4}{*}{ Religious } & Orthodox & $203(53.0 \%)$ \\
\hline & Muslim & II3 (29.5\%) \\
\hline & Protestant & 57 (I4.9\%) \\
\hline & Others & $12(3.1 \%)$ \\
\hline
\end{tabular}


of the clinic, 298 (77.8); and location and availability of laboratory service, $295(77.0 \%)$ Table 2.

\section{Factors Associated with Client Satisfaction}

The results from the bivariate analysis showed that there was association between Age group, Marital status, Ethnicity, Educational level, Occupational status, Religious, Consultation time, Average waiting time, Length on ART and Estimated Monthly income with level of patients' satisfaction toward ART services provision ( $\mathrm{P}$ value $<0.25$ ). Furthermore, statistically significant associations were found between the overall satisfaction of the clients with average waiting time to get service and duration of stay on ART with $\mathrm{p}<0.05$. Results of multiple logistic regression analysis showed that patients who waited 31-60 minutes to get services were $71.3 \%$ less likely to be satisfied than those who waited less than 15 minutes to get service $(\mathrm{AOR}=0.287$, 95\% CI: $0.07-$ 0.0771). Moreover, those clients who stayed 36-60 months on ART treatment were $82.5 \%$ less likely to be satisfied than those who stayed less than 12 months on ART treatment $(\mathrm{AOR}=0.175,95 \% \mathrm{CI}: 0.04-0.771)$ as shown in Table 3.

\section{Discussion}

This study has revealed that overall client satisfaction level with the ART services was $85.5 \%$, which showed a majority of the respondents were satisfied with almost all aspects of ART services they received. This finding was similar with study conducted in Tehran that found $82 \%$ of patients were satisfied with ART service they received. ${ }^{19}$ The result of the present study has also showed higher patient satisfaction rate than studies conducted in Jimma and Tigray that showed $57.1 \%$ and $43.6 \%$ respectively. ${ }^{3,20}$

Results of this study show that most of the respondents said the ARV drugs were available at the clinics but they complained of long times spent waiting for consultation. It has been shown that if patients wait less than 30 minutes, usually they are satisfied. ${ }^{21}$ One of the reasons why patients had to wait for a long time is that there is late opening time of the clinic while a large number of HIV patients attending the clinics and few HCPs provide the services. Results on privacy during consultation with the HCPs indicate that the study clinic is doing well as a majority (93\%) of the patients reported privacy during consultation at the clinics. When providing services to the patient privacy is necessary, since
Table 2 Respondents Level of Satisfaction with ART Service Provision in Jimma Town Public Health Facilities, Southwest, Ethiopia, June, $2018(\mathrm{~N}=383)$

\begin{tabular}{|l|l|l|}
\hline Variables & Satisfied & Dissatisfied \\
\hline Availability of ARV drugs & $375(97.9 \%)$ & $8(2.1 \%)$ \\
\hline Availability of non-ARV drugs & $350(91.4 \%)$ & $33(8.6 \%)$ \\
\hline $\begin{array}{l}\text { Availability of laboratory services } \\
\text { (CD4) }\end{array}$ & $295(77.0 \%)$ & $88(23.0 \%)$ \\
\hline Opening hours of the clinic & $298(77.8 \%)$ & $85(22.2 \%)$ \\
\hline Easy access to ART service & $344(89.8 \%)$ & $39(10.2 \%)$ \\
\hline Respect health care providers show & $346(90.3 \%)$ & $37(9.7 \%)$ \\
\hline Counseling service given by HCPs & $349(91.1 \%)$ & $34(8.9 \%)$ \\
\hline Chance given to ask and talk feeling & $356(93.0 \%)$ & $27(7.0 \%)$ \\
\hline $\begin{array}{l}\text { Confidentiality of medical } \\
\text { information }\end{array}$ & $357(93.2 \%)$ & $26(6.8 \%)$ \\
\hline $\begin{array}{l}\text { Information provided by HCPs } \\
\text { Competency of health care provider }\end{array}$ & $356(93.0 \%)$ & $27(7.0 \%)$ \\
\hline $\begin{array}{l}\text { Service received from the facility } \\
\text { today }\end{array}$ & $347(90.6 \%)$ & $36(9.4 \%)$ \\
\hline $\begin{array}{l}\text { Privacy not to be seen or heard by } \\
\text { others }\end{array}$ & $356(93.0 \%)$ & $27(7.0 \%)$ \\
\hline $\begin{array}{l}\text { Cleanliness \& attractiveness of the } \\
\text { clinic }\end{array}$ & $340(88.8 \%)$ & $43(11.2 \%)$ \\
\hline Waiting time for service & 352 (91.9\%) & $31(8.1 \%)$ \\
\hline Prescription for his or her illness & $3015(3.9 \%)$ \\
\hline
\end{tabular}

it makes the patient feel comfortable, ask questions, and understand easily the information given by the HCPs. Lack of privacy contributed to patients being unsatisfied with the services. Similar results were reported by other studies. ${ }^{21-23}$ Regarding counseling service given by HCPs, a majority of patients $(349,91.1 \%)$ reported being satisfied with the counseling. Our finding is contrary to other study results that patients were unsatisfied with the counseling on ARV side effects and dispensing process. ${ }^{21,24}$ Usually patients need health care provider to explain about medications. Communicating with patients about medications, especially on use and side effects has positive effects on their 
Table 3 Bivariate and Multivariate Analysis Showing Factors Associated with Patient Satisfaction on the ATR Service Provision in Jimma Town Public Health Facilities, Southwest, Ethiopia, June, 2018 ( $N=383)$

\begin{tabular}{|c|c|c|c|c|c|c|}
\hline & Variables & $N=383$ & COR & P-value $(95 \% \mathrm{CI})$ & AOR & P-value $(95 \% \mathrm{Cl})$ \\
\hline Age group & $\begin{array}{l}18-27 \\
28-37 \\
38-47 \\
48-57 \\
58 \text { and above }\end{array}$ & $\begin{array}{l}46 \\
163 \\
99 \\
44 \\
31\end{array}$ & $\begin{array}{l}1.15 \\
2.04 \\
1.4 \\
2.6\end{array}$ & $\begin{array}{l}0.76(0.45-2.89) \\
0.19 *(0.69-6.02) \\
0.59(0.41-4.79) \\
0.25(0.50-13.46)\end{array}$ & $\begin{array}{l}1.286 \\
2.828 \\
2.164 \\
2.441\end{array}$ & $\begin{array}{l}0.698(0.36-4.57) \\
0.166(0.65-12.31) \\
0.369(0.40-11.66) \\
0.372(0.34-17.31)\end{array}$ \\
\hline Marital status & $\begin{array}{l}\text { Single } \\
\text { Married } \\
\text { Divorce } \\
\text { Widowed } \\
\text { Separated }\end{array}$ & $\begin{array}{l}42 \\
195 \\
41 \\
44 \\
61\end{array}$ & $\begin{array}{l}1.57 \\
1.44 \\
1.56 \\
2.24\end{array}$ & $\begin{array}{l}0.33(0.62-3.96) \\
0.56(0.41-4.96) \\
0.48(0.45-5.36) \\
0.19 *(0.65-7.60)\end{array}$ & $\begin{array}{l}1.060 \\
1.171 \\
1.285 \\
1.570\end{array}$ & $\begin{array}{l}0.933(0.27-4.06) \\
0.854(0.21-6.29) \\
0.768(0.24-6.82) \\
0.590(0.30-8.09)\end{array}$ \\
\hline Ethnic group & $\begin{array}{l}\text { Oromo } \\
\text { Amhara } \\
\text { Kafa } \\
\text { Dawuro } \\
\text { Others }\end{array}$ & $\begin{array}{l}172 \\
87 \\
49 \\
36 \\
38\end{array}$ & $\begin{array}{l}I .4 I \\
0.88 \\
0.76 \\
0.54\end{array}$ & $\begin{array}{l}0.45(0.56-3.45) \\
0.80(0.32-2.35) \\
0.62(0.26-2.23) \\
0.2 I *(0.2 I-I .4 I)\end{array}$ & $\begin{array}{l}0.747 \\
0.48 I \\
0.336 \\
0.268\end{array}$ & $\begin{array}{l}0.625(0.23-2.4 I) \\
0.267(0.13-1.74) \\
0.128(0.08-1.36) \\
0.037^{* *}(9.07-0.92)\end{array}$ \\
\hline Educational status & $\begin{array}{l}\text { Unable read and write } \\
\text { Read \& write only } \\
\text { Elementary school } \\
\text { Secondary school } \\
\text { College and above }\end{array}$ & $\begin{array}{l}68 \\
22 \\
149 \\
108 \\
36\end{array}$ & $\begin{array}{l}3.62 \\
1.66 \\
1.52 \\
0.61\end{array}$ & $\begin{array}{l}0.23 *(0.4-30.0 I) \\
0.25(0.6-3.9) \\
0.37(0.6 I-3.8) \\
0.33(0.2-1.67)\end{array}$ & $\begin{array}{l}2.541 \\
1.520 \\
1.244 \\
0.412\end{array}$ & $\begin{array}{l}0.417(0.26-24.16) \\
0.418(0.55-4.19) \\
0.719(0.38-4.07) \\
0.254(0.09-1.89)\end{array}$ \\
\hline Occupational status & $\begin{array}{l}\text { Unemployed } \\
\text { Gov't employee } \\
\text { Farmer } \\
\text { Merchant } \\
\text { Private employee } \\
\text { Others }\end{array}$ & $\begin{array}{l}75 \\
64 \\
12 \\
74 \\
114 \\
44\end{array}$ & $\begin{array}{l}0.62 \\
1.13 \\
0.98 \\
0.54 \\
2.16\end{array}$ & $\begin{array}{l}0.38(0.2-1.7) \\
0.91(0.12-10.17) \\
0.97(0.32-2.96) \\
0.20 *(0.22-1.38) \\
0.35(0.42-10.90)\end{array}$ & $\begin{array}{l}0.829 \\
0.776 \\
0.625 \\
0.404 \\
2.021\end{array}$ & $\begin{array}{l}0.791(0.2 I-3.31) \\
0.836(0.07-8.57) \\
0.501(0.16-2.45) \\
0.109(0.13-1.22) \\
0.446(0.33-12.33)\end{array}$ \\
\hline Religious & $\begin{array}{l}\text { Orthodox } \\
\text { Muslim } \\
\text { Protestant } \\
\text { Others }\end{array}$ & $\begin{array}{l}203 \\
113 \\
57 \\
12\end{array}$ & $\begin{array}{l}0.74 \\
0.38 \\
0.48\end{array}$ & $\begin{array}{l}0.45(0.35-1.59) \\
0.02 *(0.17-0.83) \\
0.37(0.09-2.39)\end{array}$ & $\begin{array}{l}0.509 \\
0.290 \\
0.580\end{array}$ & $\begin{array}{l}0.214(0.17-1.47) \\
0.019 * *(0.13-0.81) \\
0.560(0.09-3.63)\end{array}$ \\
\hline Consultation time & $\begin{array}{l}\leq 10 \text { minute } \\
11-20 \text { minute } \\
21-30 \text { minute }\end{array}$ & $\begin{array}{l}334 \\
36 \\
13\end{array}$ & $\begin{array}{l}0.74 \\
0.43\end{array}$ & $\begin{array}{l}0.57(0.27-2.04) \\
0.18^{*}(0.10-1.53)\end{array}$ & $\begin{array}{l}0.772 \\
0.257\end{array}$ & $\begin{array}{l}0.679(0.26-2.63) \\
0.102(0.05-1.31)\end{array}$ \\
\hline Average waiting time & $\begin{array}{l}\leq 15 \text { minutes } \\
16-30 \text { minutes } \\
31-60 \text { minutes } \\
\geq 61 \text { minutes }\end{array}$ & $\begin{array}{l}136 \\
123 \\
86 \\
38\end{array}$ & $\begin{array}{l}0.81 \\
0.38 \\
0.58\end{array}$ & $\begin{array}{l}0.63(0.35-1.97) \\
0.02 *(0.16-0.87) \\
0.34(0.18-1.78)\end{array}$ & $\begin{array}{l}0.639 \\
0.287 \\
0.353\end{array}$ & $\begin{array}{l}0.369(0.24-1.69) \\
0.013^{* *}(0.11-0.77) \\
0.109(0.09-1.26)\end{array}$ \\
\hline Length of stay on ART & $\begin{array}{l}\leq 12 \text { Months } \\
12-36 \text { Months } \\
36-60 \text { Months } \\
>60 \text { Months }\end{array}$ & $\begin{array}{l}59 \\
74 \\
73 \\
177\end{array}$ & $\begin{array}{l}0.44 \\
0.27 \\
0.4\end{array}$ & $\begin{array}{l}0.24 *(0.11-1.75) \\
0.03 *(0.06-0.91) \\
0.17 *(0.12-1.47)\end{array}$ & $\begin{array}{l}0.306 \\
0.175 \\
0.349\end{array}$ & $\begin{array}{l}0.139(0.06-1.47) \\
0.02 I^{* *}(0.04-0.7 \mathrm{I}) \\
0.144(0.08-1.43)\end{array}$ \\
\hline Estimated Monthly income & $\begin{array}{l}0-500 \\
50 I-1000 \\
100 I-2000 \\
200 I-3000 \\
\text { More than } 3000\end{array}$ & $\begin{array}{l}222 \\
78 \\
47 \\
19 \\
17\end{array}$ & $\begin{array}{l}0.6 \\
1.7 \\
1.79 \\
0.5\end{array}$ & $\begin{array}{l}0.72(0.06-6.59) \\
0.19 *(0.75-3.87) \\
0.35(0.53-6.09) \\
0.17 *(0.18-1.37)\end{array}$ & $\begin{array}{l}0.443 \\
1.792 \\
2.255 \\
0.538\end{array}$ & $\begin{array}{l}0.585(0.02-8.19) \\
0.267(0.64-5.02) \\
0.297(0.48-10.34) \\
0.404(0.13-2.3)\end{array}$ \\
\hline
\end{tabular}

Notes: $* \mathrm{P} \leq 0.25, * * \mathrm{P} \leq 0.01$. 
perceptions of pain and responsiveness, which is associated with patient satisfaction. ${ }^{25}$ One of the predictors of satisfaction is the waiting time to get services. In this study those patients who have short waiting time to get services were more satisfied than those who have long waiting time. Our results are similar to other studies who reported that majority of patients were satisfied with the time spent waiting for the services (less than 30 minutes). ${ }^{21,23}$

In conclusion, the overall satisfaction survey showed that most respondents were satisfied with ART services provision. However, factors such as waiting times before service, duration of stay on ART were independently predictors of patient satisfaction. Therefore, providing service timely and shortening patients' waiting time before service and giving due attention for patients, those who have took ARV for long times may increase client satisfaction in the facilities.

\section{Acknowledgments}

The study was funded by Jimma University, Institute of Health. We would like to acknowledge study subjects and participating staff of each facility for their administrative support and cooperation.

\section{Author Contributions}

All authors contributed to data analysis, drafting or revising the article, have agreed on the journal to which the article will be submitted, gave final approval of the version to be published, and agree to be accountable for all aspects of the work.

\section{Disclosure}

All authors declare that they have no conflicts of interest associated with the publication of this manuscript.

\section{References}

1. Ministry of Health FDR of E. Federal Democratic Republic of Ethiopia Ministry of Health National Guidelines for Comprehensive HIV Prevention, Care and Treatment. 2014. p-1.

2. World Health Organization. Antiretroviral Therapy for Adults and Adolescents: Recommendations for a Public Health Approach. World Health Organization. 2006; 1-134.

3. Atsebeha KG, Chercos DH. High antiretroviral therapy service delivery satisfaction and its' associated factors at Midre-genet hospital; Northwest Tigray, Ethiopia. BMC Health Serv Res. 2018;18(1):1-9. doi:10.1186/s12913-018-3055-4

4. Ministry of Health of Ethiopia. National Guidelines for HIV \& AIDS Care and Treatment. 2014.

5. Office C. Guidelines for Paediatric HIV/AIDS Care and Treatment in Ethiopia Federal HIV/AIDS Prevention and Control Office Federal Ministry of Health July 2007 Table of Contents. 2007.

6. Ontario Ministry of Health. Guidelines for HIV counselling and testing in Ethiopia; 2008. Available from: www.health.gov.on.ca/HIV. Accessed June 17, 2021.
7. ORHB. Comprehensive HIV/AIDS Prevention, Treatment and Care Service. 2014.

8. Azuike EC, Adinma ED, Umeh UM, Njelita IA, Anemeje OA, Aniemena RC. Client's satisfaction with waiting time in HIV treatment centers: an urban rural comparison in Anambra State, Nigeria. Epidemiol Open Access. 2017;07(01).

9. Oche M, Raji M, Kaoje A, et al. Clients' satisfaction with antiretroviral therapy services in a tertiary hospital in Sokoto, Nigeria. J AIDS HIV Res. 2013;5(9):328-333.

10. Orsini N, Naburi H, Mujinja P, et al. Predictors of patient dissatisfaction with services for prevention of mother-to-child transmission of HIV in Dar es Salaam. PLoS One. 2016;1-15.

11. Bezuidenhout S, Ogunsanwo DA, Helberg EA, et al. Patient satisfaction at accredited antiretroviral treatment sites in the Gert Sibande District. 2021. 1-6.

12. Evaluation $\mathrm{U}$ of $\mathrm{NC}$ at $\mathrm{CHCPCM}$, Health $\mathrm{U}$ of GS of $\mathrm{P}$, Commission GA. A performance evaluation of the National HIV Prevention Program for FSW and MSM in Ghana; 2014. Available from: http://www.cpc.unc.edu/measure/publications/tr-14-97. Accessed June 17, 2021.

13. Himakalasa W, Grisurapong S, Phuangsaichai S. Access to antiretroviral therapy among HIV/AIDS patients in Chiang Mai province, Thailand. HIV/AIDS Res Palliat Care. 2013;5:205-213. doi:10.2147/HIV.S49729

14. Doyore F, Moges B. Client satisfaction to antiretroviral treatment services and associated factors among clients attending ART clinics in. Clin Res Trials Res. 2016;2(6).

15. Dansereau E, Masiye F, Gakidou E, Masters SH, Burstein R, Kumar S. Patient satisfaction and perceived quality of care: evidence from a cross-sectional national exit survey of HIV and non-HIV service users in Zambia. Open Access. 2015;1-11.

16. Dixit S, Verma N, Shrivastava N, Sharma M, Pradhan SK, Agarwal S. Patient satisfaction with ART centre services among people living with HIV: a cross sectional study in a tertiary care hospital. Int J Commun Med Public Health. 2018;5(6):2564-2571. doi:10.18203/2394-6040.ijcmph20182195

17. Eshetu A, Gobena T, Mengeste B, Semahegn A. Quality of clinical care for people living with HIV/AIDS in DilChora Referral Hospital, Dire Dawa, East Ethiopia. Pharma Innov. 2013;(January 2005):1-9.

18. Alasad J, Abu Tabar N, AbuRuz ME. Patient satisfaction with nursing care. JONA J Nurs Adm. 2015;45(11):563-568. doi:10.1097/ NNA.0000000000000264

19. Prevention HI V, For C, Populations KEY. Supplement To the 2014 Consolidated Guidelines for Hiv Prevention, Diagnosis, Treatment and Care for Key Populations Tool To Set and Monitor Targets for Hiv Prevention, Diagnosis, Treatment and Care for Key Populations. 2015.

20. Getenet H, Abraham Haileamlak AT. 'Clients' satisfaction with anti retroviral therapy services at Jimma University specialized hospital. Ethiop J Health Sci. 2008;18.

21. Gab K, Rwebangila F. Patient satisfaction with health care services provided at HIV clinics at Amana and Muhimbili hospitals in Dar es Salaam. Afri Health Sci. 2011;11(1).

22. Tsasis P, Christos Tsoukas GD. Evaluation of patient satisfaction in a specialized HIV/AIDS care unit of a major hospital. AIDS Patient Care STDs. 2002;14(7).

23. Muhondwa EPY, Leshabary MT, Mwangu M, Mbembati NEM. Patient satisfaction at the Muhimbili National Hospital in Dar es Salaam Tanzania. East Afr J Public Health. 2008;5(2):67-73.

24. Marquez-Peiro JF-P-PC. Evaluation of Patient satisfaction in outpatient pharmacy. Farm Hosp. 2008;32(2):71-76.

25. Anderson RT, Camacho FTBR, Balkrishnan R. Willing to wait?: the influence of patient wait time on satisfaction with primary care. $B M C$ Health Serv Res. 2007;7(31). doi:10.1186/1472-6963-7-31 


\section{Publish your work in this journal}

HIV/AIDS - Research and Palliative Care is an international, peerreviewed open-access journal focusing on advances in research in HIV, its clinical progression and management options including antiviral treatment, palliative care and public healthcare policies to control viral spread. The manuscript management system is completely online and includes a very quick and fair peer-review system, which is all easy to use. Visit http://www.dovepress.com/testimonials.php to read real quotes from published authors.

Submit your manuscript here: https://www.dovepress.com/hivaids—research-and-palliative-care-journal 